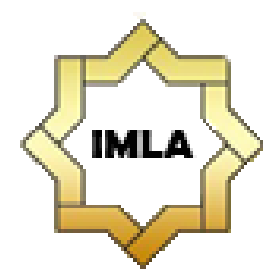

Al-Ta'rib

Jurnal Ilmiah Program Studi Pendidikan Bahasa Arab

IAIN Palangka Raya

Vol. 8, No. 1, June 2020, 17-32

p-ISSN 2354-5887 | e-ISSN 2655-5867

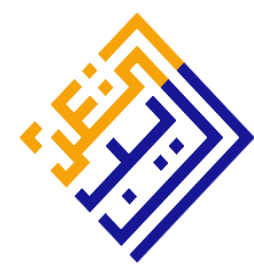

\title{
MULTIMEDIA INTERAKTIF \\ UNTUK MENGATASI PROBLEMATIKA PEMBELAJARAN BAHASA \\ ARAB
}

\author{
Aulia Mustika Ilmiani' ${ }^{1}$ Ahmadi', Nur Fuadi Rahman ${ }^{3}$, Yulia Rahmah4 \\ 1,2,3,4Institut Agama Islam Negeri Palangka Raya, Indonesia \\ E-mail: aulia.mustika.ilmiani@iain-palangkaraya.ac.id
}

\begin{abstract}
The use of media, especially in learning Arabic in Indonesia has been proven to be significant. Many studies prioritize the use of certain media in the learning process so that it can overcome the problems of learning Arabic. This descriptive qualitative study discusses the use of interactive multimedia in learning Arabic at IAIN Palangka Raya. This study aims to explore interactive multimedia used by PBA lecturers to overcome the problems of learning Arabic. Data collection techniques used are observation, interviews and documentation. The results of the study are: first, in terms of time and place of implementation, namely IAIN Palangka Raya e-learning, Arabic online and Bahasaarab312.gnomio.com. Second, viewed from the materials being taught, multimedia PowerPoint was used which included cartoon story maker media, Arabic Online, camtasia, active presenter, e-book learning, YouTube, kine master, pollagon, Arabee. Third, seen from the needs of students, Macromedia / Adobe Flash was relevant. The Arabic learning problems that can be overcome with the use of interactive multimedia are as follows. 1) In terms of linguistics, using interactive multimedia, lecturers become easier in demonstrating teaching or learning materials to 2) in terms of practical (non-linguistic) using multimedia interactive, PBA lecturers can attract the students interests and attention who lack of motivation in learning Arabic.
\end{abstract}

Keywords: Interactive multimedia; problems

\begin{abstract}
Abstrak
Penggunaan media, khususnya dalam pembelajaran bahasa Arab di Indonesia terbukti signifikan. Banyak penelitian yang mengutamakan penggunaan media tertentu dalam proses pembelajaran sehingga dapat mengatasi problematika pembelajaran bahasa Arab. Penelitian kualitatif deskriptif ini membahas tentang penggunaan multimedia interaktif dalam pembelajaran Bahasa Arab di IAIN Palangka Raya. Penelitian ini bertujuan untuk mengeksplorasi multimedia interaktif yang digunakan oleh dosen-dosen PBA untuk mengatasi problematika pembelajaran bahasa Arab. Tekhnik pengumpulan data yang digunakan adalah observasi, wawancara dan dokumentasi. Hasil penelitian yang didapatkan adalah: pertama, dilihat dari segi waktu dan tempat pelaksanaanya yaitu Simak e-learning IAIN
\end{abstract}


Palangka Raya, Arabic online dan Bahasaarab312.gnomio.com. Kedua, dilihat dari materi yang diajarkan, yaitu multimedia powerpoint yang mencakup media cartoon story Maker, Arabic Online, camtasia, active presenter, e-book learning, youtube, kine master, pollagon, Arabee. Dan ketiga, dilihat dari kebutuhan mahasiswa, yaitu macromedia/ Adobe Flash. Adapun problematika pembelajaran bahasa Arab yang dapat teratasi dengan penggunaan multimedia interaktif ini adalah: 1) dari segi linguistik, dengan menggunakan multimedia interaktif, dosen menjadi lebih mudah dalam mendemonstrasikan bahan ajar atau materi pembelajaran kepada 2) dari segi praktis (Non lingusitik) dengan menggunakan multimedia interaktif, dosen PBA dapat menarik minat dan perhatian mahasiswa yang kurang mempunyai motivasi dalam belajar bahasa arab.

\section{Kata Kunci: Multimedia interaktif; Problematika}

\section{Pendahuluan}

Dewasa ini, dengan kemajuan dalam komunikasi dan informasi, multimedia dan teknologi baru lainnya, paradigma pendidikan telah bergeser dari instruksi berbasis konvensional ke instruksi berbasis teknologi (Rho \& Kang, 2019). Konsep pembelajaran yang berorientasi teknologi (technology conception of education) adalah suatu keharusan yang tak dapat dihindarkan. Perkembangan teknologi informasi telah memberikan pengaruh yang sangat signifikan dalam perkembangan media pembelajaran. Sebagaimana diketahui, kehadiran teknologi ini telah mampu mengintegrasikan berbagai jenis media kedalam model pembelajaran (Rukimin, 2016). Bahkan, disebutkan oleh Armawi, bahwa Teknologi pembelajaran bukan hanya alat untuk menghasilkan suatu produk, melainkan juga merupakan suatu sistem penalaran logis dalam rangka konseptualisasi dan pengembangan pembelajaran secara tepat, cepat, padat dan hemat (Armawi, 2018).

Proses pengembangan pembelajaran yang dimungkinkan oleh teknologi penginderaan sadar konteks dapat dieksplorasi, sehingga lebih mudah mengungkapkan cara-cara spesifik untuk menerapkan teknologi baru di lingkungan formal dan informal (Lin et al., 2019). Berdasarkan analisis hasil pembelajaran yang dimaksudkan menunjukkan bahwa lebih banyak upaya harus diarahkan untuk mendorong kompetensi dalam menganalisis dan menciptakannya dalam proses pembelajaran. Sehubungan dengan hal tersebut, semua jenis pembelajaran termasuk pembelajaran bahasa Arab, perlu diorientasikan kepada penggunaan teknologi. Salah satu ragam teknologi yang sampai hari ini marak digunakan adalah ragam teknologi dari segi multimedia yang merupakan salah satu alternatif yang dapat digunakan untuk membantu mengatasi masalah belajar peserta didik (Baso, 2008), karena dengan menggunakan teknologi multimedia, hal ini dapat bermanfaat.

Pertama, untuk peserta didik sehingga peserta didik mampu belajar secara mandiri, lebih mudah, nyaman, dan belajar sesuai dengan kemampuannya tanpa kendala eksternal. Dan kedua, untuk pengajar sehingga pengajar dapat fokus berperan sebagai fasilitator dalam proses pembelajaran (Yasmar, 2017).

Realita saat ini memperlihatkan bahwa belajar dan mengajar bahasa asing, termasuk bahasa Arab merupakan pekerjaan yang "sulit" dan relatif melelahkan. 
Berbagai cara ditempuh oleh tenaga pengajar dalam mendesain pembelajaran hingga tercipta suasana yang menstimulasi belajar siswa/mahasiswa dengan mudah. Dengan ini multimedia sebagai salah satu sarana yang dapat menyalurkan pesan dan memegang peranan penting dalam menunjang keberhasilan proses pembelajaran. Perbedaan gaya belajar, kemampuan peserta didik, intelegensi, keterbatasan daya indera, hambatan jarak waktu dan lain-lain, dapat diatasi dengan pemanfaatan multimedia dengan baik dan benar. Bahkan, beberapa institusi pendidikan dalam negeri mulai menerapkan pembelajaran (learning) yang terbuka dan fleksibel. Dalam pembelajaran seperti ini, siswa/mahasiswa menghadiri pertemuan dalam kelas, namun pada waktu yang lain mereka belajar melalui sistem jarak jauh.

Sebagaimana halnya yang dilakukan oleh dosen-dosen PBA di IAIN Palangka Raya, yang mulai konsisten mendayagunakan multimedia interaktif dalam proses pembelajaran bahasa Arab pada setiap mata kuliah. Konsistensi ini ditegaskan dengan usaha yang dilakukan oleh dosen PBA dalam mengikuti berbagai pelatihan berbagai media inovatif yang kemudian dapat diaplikasikan secara nyata, dalam proses pembelajaran sehari-hari. Salah satu pelatihan yang diikuti oleh Dosen PBA yaitu pelatihan pembuatan video e-module (Dosen PBA Mengikuti Workhsop Pembuatan Video Pembelajaran Interaktif Dan E-Module 4.0, n.d.), yang mana kemudian dari pelatihan ini, dosen PBA dapat mengembangkan multimedia interaktif sebagaimana yang dibutuhkan. Upaya ini adalah tindak cepat yang diberlakukan untuk mengatasi berbagai problematika pembelajaran linguistik maupun nonlinguistik yang dapat mengurangi kualitas pembelajaran bahasa Arab pada prodi PBA IAIN Palangka Raya. Sebagaimana yang dijelaskan oleh Haniah, menurutnya pembelajaran bahasa Arab, tidak terlepas dari permasalahan dan kesulitan-kesulitan belajar. Kehadiran teknologi pembelajaran baik itu multimedia dan jika dimanfaatkan dalam proses pembelajaran, maka dapat mengatasai dan memberi jalan keluar dalam mengatasi problema pembelajaran bahasa Arab terkhusus di Indonesia (Haniah, 2014).

Adapun problematika pembelajaran Bahasa Arab yang terjadi pada prodi PBA IAIN Palangka Raya, dapat ditinjau menjadi dua bagian yaitu problematika linguistik dan problematika praktis (nonlinguistic). Sebagaimana problematika yang terjadi pada umumnya. Dijelaskan oleh Fahrurrozi dalam artikelnya, bahwa pengajaran bahasa Arab di Indonesia sering kali menghadapi problem linguistik dan nonlinguistik yang harus segera dituntaskan. Problem linguistik, seperti fonetik, morfologi, dan struktur, sedangkan problem non-linguistik, antara lain, motivasi belajar, sarana belajar, metode pengajaran, waktu belajar, dan lingkungan pembelajaran (Fahrurrozi, 2014). Persoalan pembelajaran bahasa arab pada dasarnya memang sangat bervariasi sesuai dengan usia pelajar dan lingkungan tempat belajar. Hal serupa juga terjadi pada prodi PBA IAIN Palangka Raya, terdapat dua masalah pokok yang sampai hari ini masih menjadi persoalan bersama. Pertama, yang bersifat linguistic seperti mengenali tata bunyi, kosakata, tata kalimat, dan tulisan. Kedua, masalah yang bersifat non linguistik yaitu menyangkut segi sosio-kultural atau sosio budaya.

Dalam penelitian ini digambarkan bahwa pembelajaran bahasa Arab hendaknya disesuaikan dengan kemajuan zaman agar dapat menghandle semua kebutuhan mahasiswa. Perkembangan zaman, membuat multimedia interaktif juga 
secara cepat berkembang masif. Sehingga dosen dan mahasiswa, juga pegiat pembelajar bahasa Arab lainnya hendaknya tidak serta merta berdiam diri dengan proses pembelajaran yang seadanya. Sementara banyak cara yang dapat dilakukan agar proses pembelajaran lebih interaktif dan menarik. Salah satunya adalah dengan memanfaatkan multimedia interaktif ini sebagai penunjang keberhasilan dalam mengatasi berbagai macam problematika pembelajaran bahasa Arab. Kontribusi penting dalam penelitian ini adalah bahwa sebagai dosen atau pengajar dalam pembelajaran Bahasa Arab, penting kiranya memanfaatkan multimedia pembelajaran yang dapat memfasilitasi kebutuhan mahasiswa yang beragam. Apabila menggunakan satu media pembelajaran saja dirasa belum efektif, maka tidak ada salahnya dengan mencoba berbagai macam media yang dirasa menguntungkan dalam proses pembelajaran. Sehingga sebagai seorang dosen atau pengajar bahasa Arab, kita pun harus cakap dalam memanfaatkan multimedia yang ada disekitar kita. Adapun perbedaan penelitian ini dengan penelitian sebelumnya adalah penelitian ini akan menguraikan secara lebih luas, beragam multimedia yang dilakukan oleh dosen-dosen PBA IAIN Palangka Raya, yang kiranya dapat menjadi referensi atau rujukan bagi dosen atau pengajar bahasa Arab lain sebagai salah satu opsi pembelajaran menarik dengan tujuan memfasilitasi beragam kebutuhan mahasiswa dan juga untuk mengatasi problematikan pembelajaran bahasa Arab itu sendiri.

Oleh sebab itu tujuan penelitian ini adalah berfokus untuk mengeksplorasi lebih lanjut mengenai pendayagunaan multimedia interaktif yang digunakan oleh dosen-dosen PBA IAIN Palangka Raya dalam mengatasi berbagai macam problematika yang muncul dalam proses pembelajaran. Serta ulasan lengkap mengenai problematika apa saja yang dapat teratasi, setelah menggunakan multimedia interaktif tersebut.

\section{Multimedia Interaktif}

Multimedia jika ditinjau dari bahasanya terdiri dari 2 kata yaitu multi dan media. Multi yang berarti banyak atau lebih dari satu, sementara media merupakan bentuk jamak dari medium yang berarti sarana wadah atau alat. Pengertian yang lain disampaikan oleh Gagne dan Briggs, media adalah komponen sumber belajar atau peralatan fisik yang mengandung materi pembelajaran di lingkungan belajar yang dapat merangsang peserta didik untuk belajar. Sedangkan, menurut National Education Association/ NEA, media adalah bentuk-bentuk komunikasi baik literal maupun audiovisual serta peralatannya (Angelina \& Hamdun, 2019).

Istilah multimedia sendiri dapat diartikan sebagai transmisi data dan manipulasi segala bentuk informasi baik dalam bentuk teks, gambar, video, audio, angka atau kata kata di mana dalam dunia komputer bentuk informasi tersebut diolah dalam bentuk data digital (Jarot.S \& Ananda, 2009). Hal ini sejalan dengan pendapat Vaughan dalam artikel Rukimin (Rukimin, 2016), ia menyebutkan multimedia merupakan kombinasi teks, seni suara, gambar, animasi, dan video dengan menggunakan komputer atau diinovasi secara digital. Ditambahkan juga oleh Hoftetter, bahwa multimedia tidak hanya pemanfaatan komputer untuk membuat dan menggabungkan teks, grafik, audio, gambar bergerak (video dan animasi) namun juga, multimedia berperan dalam menggabungkan link dan tool yang memungkinkan pemakai menggunakan navigasi, berinteraksi, berkreasi dan berkomunikasi (Binanto, 2010). 
Ada tiga jenis multimedia, yang pertama adalah multimedia interaktif, yakni pengguna dapat mengontrol apa dan kapan elemen-elemen dalam multimedia akan dikirimkan atau ditampilkan; yang kedua adalah Multimedia hiperaktif, yakni jenis multimedia ini mempunyai struktur dari elemen-elemen terkait dengan pengguna yang dapat mengarahkannya. Dengan kata lain, multimedia jenis ini memiliki banyak tautan (link) yang menghubungkan elemen-elemen multimedia yang ada; dan yang ketiga adalah Multimedia linier, yakni pengguna hanya menjadi penonton dan menikmati produk (Rukimin, 2016). Dari tiga jenis ini, yang digunakan dalam proses pembelajaran Bahasa Arab pada prodi PBA di IAIN Palangka Raya adalah multimedia interaktif, hal ini diutarakan oleh dosen-dosen PBA yang peneliti wawancarai, dengan alasan multimedia interaktif lebih fungsional digunakan dalam situasi dan lingkungan kegiatan pembelajaran dikampus.

Secara lebih ringkas Armawi, menjelaskan multimedia interaktif adalah Sistem yang menggunakan lebih dari satu media presentasi (Teks, Suara, Animasi dan Video) secara bersamaan dan melibatkan keikutsertaan pemakai untuk memberi perintah, mengendalikan dan memanipulasi (Armawi, 2018). Hal yang sama diutarakan oleh Ariani dan Haryanto, mereka mengungkapkan karakteristik multimedia interaktik adalah sebagai berikut: (1) Memiliki lebih dari satu media yang konvergen, misalnya menggabungkan unsur audio dan visual; (2) Bersifat interaktif, dalam pengertian memiliki kemampuan untuk mengakomodasi respon pengguna; (3) Bersifat mandiri, dalam pengertian memberi kemudahan dan kelengkapan isi sedemikian rupa sehingga pengguna bisa menggunakan tanpa bimbingan orang lain; (4) Mampu memberikan kesempatan kepada peserta didik untuk mengontrol laju kecepatan belajarnya sendiri; (5) Memperhatikan bahwa peserta didik mengikuti suatu urutan yang koheren dan terkendali (Handayani, 2017).

Dari berbagai pengertian ini, maka dapat disimpulkan bahwa multimedia interaktif adalah sebuah teknologi baru dengan potensi yang sangat besar untuk mengubah cara belajar, cara untuk mendapatkan informasi dan cara untuk menghibur. Dengan kata lain, multimedia interaktif merupakan cara baru untuk belajar yang paling populer dari berbagai multimedia pembelajaran.

Namun selain penggunaan multimedia interaktif secara optimal yang perlu diperhatikan adalah beberapa factor lain yang menjadi penunjang berhasilnya proses pembelajaran. Proses pembelajaran sangatlah penting, karena pembelajaran merupakan suatu pendekatan yang dapat mengembangkan pengetahuan dan keterampilan yang dimiliki oleh peserta didik juga dapat menumbuhkan jiwa sosial peserta didik antara teman dan lingkungan yang ada di sekelilingnya. Sebagaimana pendapat Sadiman (Sadiman, 2019), yang menyebutkan betapapun canggihnya, media atau multimedia yang dipilih dan digunakan bukan dimaksudkan sebagai "pengganti guru/pengajar", karena keberadaannya tidak akan membawa arti tanpa tenaga pengajar. Selain itu, dalam pemilihan media pembelajaran yang efisien dan efektif, isi dan tujuan pembelajaran haruslah sesuai dengan karakteristik media yang digunakan. Nugrawiyati menegaskan bahwa dalam proses pembelajaran, penggunaan peranan media harus sejalan dengan isi dari tujuan pembelajaran yang telah dirumuskan (Nugrawiyati, 2018). Karena itu tujuan pembelajaran harus dijadikan sebagai 
pangkal acuan untuk menggunakan multimedia interaktif tersebut. Sehingga jika diabaikan, maka multimedia interaktif yang digunakan bukan lagi menjadi alat bantu pembelajaran tetapi sebagai penghambat dalam pencapaian tujuan pembelajaran yang efektif dan efisien.

Oleh sebab itu, pada dasarnya kriteria pemilihan media harus dikembangkan sesuai dengan tujuan yang ingin dicapai, kondisi dan keterbatasan yang ada dengan mempertimpangkan kemampuan dan karakteristik multimedia itu sendiri. Muhbib berpendapat dalam artikel Armawi, bahwa pemilihan media seyogyanya tidak terlepas dari konteksnya bahwa media merupakan komponen dari sistem instruksional secara keseluruhan, yang mana meskipun tujuan dan isinya sudah diketahui, faktor-faktor lain seperti karakteristik siswa, strategi belajar-mengajar, organisasi kelompok belajar, alokasi waktu dan sumber, serta prosedur penilaiannya juga perlu dipertimbangkan sebagai pendekatan praktis, beliau menyarankan untuk mempertimbangkan media apa saja yang ada, berapa biayanya, berapa lama waktu yang dibutuhkan untuk mendapatkannya, dan format apa yang memenuhi selera pengguna baik itu pengajar ataupun peserta didik (Armawi, 2018).

Dari uraian tersebut dapat disimpulkan bahwa pendayagunaan multimedia interaktif pembelajaran bahasa Arab hendaknya dapat memperhatikan nilai praktis, ekonomis, pragmatis, dan edukatifnya bagi pengembangan aspek kognitif, afektif, dan psikomotorik siswa/mahasiswa. Idealnya ketiga aspek tersebut (kognitif, afektif, psikomotorik) dapat dicapai dan dialami siswa/mahasiswa melalui penggunaan multimedia. Selain itu, penggunaan multimedia untuk pembelajaran bahasa Arab hendaknya juga mampu memperkaya kekayaan bahasa siswa/mahasiswa, di samping membentuk lingkungan berbahasa Arab yang dinamis dan kreatif.

Adapun tujuan penggunaan multimedia interaktif dalam pembelajaran adalah: (1) Mengedepankan keaktifan peserta didik. (2) Menempatkan proses belajar sebagai proses berbagi pengetahuan. (3) Memanfaatkan non conventional ruang dan waktu. Dalam penelitiannya, Mardika juga menyebutkan multimedia interaktif bermanfaat memiliki potensi untuk menciptakan suatu lingkungan multisensori yang mendukung cara belajar tertentu (Mardika, 2018). Berdasarkan dengan hal ini, multimedia interaktif secara teoritis berfungsi sebagai berikut: (1) Multimedia dapat menimbulkan daya tarik, minat baru dan perhatian yang besar terhadap materi pelajaran. (2) Memperjelas penyajian pesan agar tidak terlalu bersifat verbalitas (dalam bentuk kata-kata tertulis atau lisan belaka). (3) Multimedia dapat mengatasi keterbatasan ruang, waktu dan daya indera. (4) Penggunaan multimedia secara tepat dan bervariasi dapat mengatasi sikap pasif anak didik. (5) Penggunaan berbagai media dengan kombinasi program yang cocok dan memadai akan meningkatkan efektivitas dan efisiensi proses belajar mengajar. (6) Media dapat menyeragamkan pemahaman dan penafsiran siswa yang berbeda-beda mengenai suatu konsep. (7) Media dapat menanamkan konsep dasar yang benar, kongkret dan realistik, sehingga perbedaan persepsi antar siswa terhadap suatu informasi dapat dihindari atau diminimalisir. (8) Media dapat memberikan pengalaman yang menyeluruh dari pengalaman yang kongkrit sampai pengalaman yang paling abstrak (Armawi, 2018). 
Selain itu, kontribusi nyata multimedia interaktif dalam proses pembelajaran menurut Kemp dan Dayton dalam artikel Nugrawiyati, adalah sebagai berikut: (1) Penyampaian pesan pembelajaran dapat lebih terstandar. (2) Pembelajaran dapat lebih menarik. (3) Pembelajaran menjadi lebih interaktif dengan menerapkan teori belajar. (4) Waktu pelaksanaan pembelajaran dapat diperpendek. (5) Kualitas pembelajaran dapat ditingkatkan. (6) Proses pembelajaran dapat berlangsung kapanpun dan dimanapun diperlukan. (7) Sikap positif siswa terhadap materi pembelajaran serta proses pembelajaran dapat ditingkatkan. (8) Peran guru mengalami perubahan ke arah yang positif (Nugrawiyati, 2018).

Ada beberapa model multimedia interaktif yang dapat digunakan untuk tujuan pembelajaran, diantaranya tutorial, drill and practice, simulasi, instructional games, hybrid, socratic, inquiry dan informational. (1) Model tutorial: Model tutorial adalah model pembelajaran yang memuat penjelasan, rumus, prinsip, bagan, tabel, definisi istilah, latihan dan branching yang sesuai. Disebut branching karena terdapat berbagai cara untuk berpindah atau bergerak melalui pembelajaran berdasarkan jawaban atau respon pengguna terhadap materi, soal-soal atau pertanyaan-pertanyaan. Jenis ini melibatkan presentasi informasi. Tutorial secara khusus terdiri dari diskusi mengenai konsep atau prosedur dengan pertanyaan bagian demi bagian atau kuis pada akhir presentasi.

(2) Model drill and practice: Model drill and practice adalah model pembelajaran yang berbantuan komputer dan memberikan praktik sebanyak mungkin terhadap kemampuan siswa. Cara kerja Drill and practice ini terdiri dari tampilan dari sebuah pertanyaan atau masalah, penerimaan respon dari pengguna, periksaan jawaban, dan dilanjutkan dengan pertanyaan lainnya berdasarkan kebenaran jawaban.

(3) Model Simulasi: Model pembelajaran dengan situasi kehidupan nyata yang dihadapi pengguna, dengan maksud untuk memperoleh pengertian global tentang proses. Simulasi digunakan untuk memperagakan sesuatu (keterampilan) sehingga pengguna merasa seperti berada dalam keadaan yang sebenarnya. Simulasi banyak digunakan pada pembelajaran materi yang membahayakan, sulit, atau memerlukan biaya tinggi, misalnya untuk melatih pilot pesawat terbang atau pesawat tempur.

(4) Model hybrid adalah gabungan dari dua atau lebih model multimedia pembelajaran. Contoh model hybrid adalah penggabungan model tutorial dengan model drill and practice dengan tujuan untuk memperkaya kegiatan pengguna, menjamin ketuntasan belajar, dan menemukan metode-metode yang berbeda untuk meningkatkan pembelajaran. Model hybrid ini memungkinkan pengembangan pembelajaran secara komprehensif dengan menyediakan seperangkat kegiatan belajar yang lengkap.

(5) Model Socratic: Model pembelajaran ini berisi percakapan atau dialog antara pengguna dengan komputer dalam natural language. (6) Model Inquiry: model pembelajaran yang dapat menjadi suatu sistem pangkalan data dan dapat dikonsultasikan oleh pengguna, dimana pangkalan data tersebut berisi data yang dapat memperkaya pengetahuan pengguna.

(7) Model Informational: model pembelajaran yang menyajikan informasi dalam bentuk daftar atau tabel. Informational menuntut interaksi yang sedikit dari pengguna (Prastiwi et al., 2020). Dari model model multimedia interaktif yang 
telah disebutkan, maka dapat disimpulkan secara lebih ringkas jika dilihat dari jenisnya, maka ada empat jenis multimedia interaktif, yaitu : (1) multimedia interaktif berbasis e-learning, (2) multimedia interaktif berbasis web/situs online, (3) multimedia interaktif berbasis software, (4) multimedia interaktif berbasis aplikasi android.

\section{Metode}

Penelitian ini merupakan penelitian kualitatif deskriptif. Penelitian kualitatif bertujuan untuk memperoleh informasi atau gambaran yang meliputi tiga aspek social yaitu tempat, pelaku, dan aktifitas yang saling berinteraksi secara sinergis. Adapun objek penelitian ini adalah pendayagunaan multimedia Interaktif oleh dosen dosen PBA IAIN Palangka Raya untuk mengatasi problematika dalam pembelajaran bahasa Arab. Adapun subjeknya adalah seluruh dosen PBA IAIN Palangka Raya. Sedangkan yang menjadi Informan adalah para mahasiswa/I PBA IAIN Palangka Raya, dan segenap teman sejawat yang berada dilingkungan IAIN Palangka Raya. Adapun tujuan dari penelitian ini adalah untuk mengetahui multimedia interaktif apa saja yang digunakan oleh dosen-dosen PBA untuk mengatasi problematika pembelajaran bahasa Arab, termasuk mengulas apa saja problematika tersebut.

Adapun tekhnik pengumpulan data yang peneliti lakukan, yaitu dengan tiga tekhnik, yaitu observasi, wawancara dan dokumentasi. Observasi yang peneliti lakukan menghabikan waktu sekitar dua bulan, terdiri dari observasi awal dan observasi pada saat proses pembelajaran berlangsung. Ada beberapa pihak yang peneliti wawancarai, yang paling utama adalah para dosen PBA IAIN Palangka Raya sebagai subjek penelitian, mahasiswa/I PBA IAIN Palangka Raya dan teman sejawat para dosen PBA IAIN Palangka Raya sebagai informan penelitian. Dan documentasi yang peneliti dapatkan adalah foto penelitian, bahan ajar yang digunakan serta multimedia interaktif yang digunakan.

Setelah data berhasil dikumpulkan, peneliti kemudian melakukan analisis data dengan menggunakan Triangulasi. Data dari hasil analisis triangulasi inilah yang kemudian menjadi hasil penelitian.

\section{Hasil dan Pembahasan}

Adapun hasil penelitian, yang penulis dapatkan mengenai pendayagunaan multimedia interaktif untuk mengatasi problematika yang muncul dalam proses pembelajaran bahasa Arab pada prodi PBA IAIN Palangka Raya telah melewati proses Analisis data dan telah diabsahkan dengan proses triangulasi sebagaimana ilustrasi pada gambar berikut : 


\section{Gambar 1. \\ Proses Analisis Data Menggunakan Triangulasi}

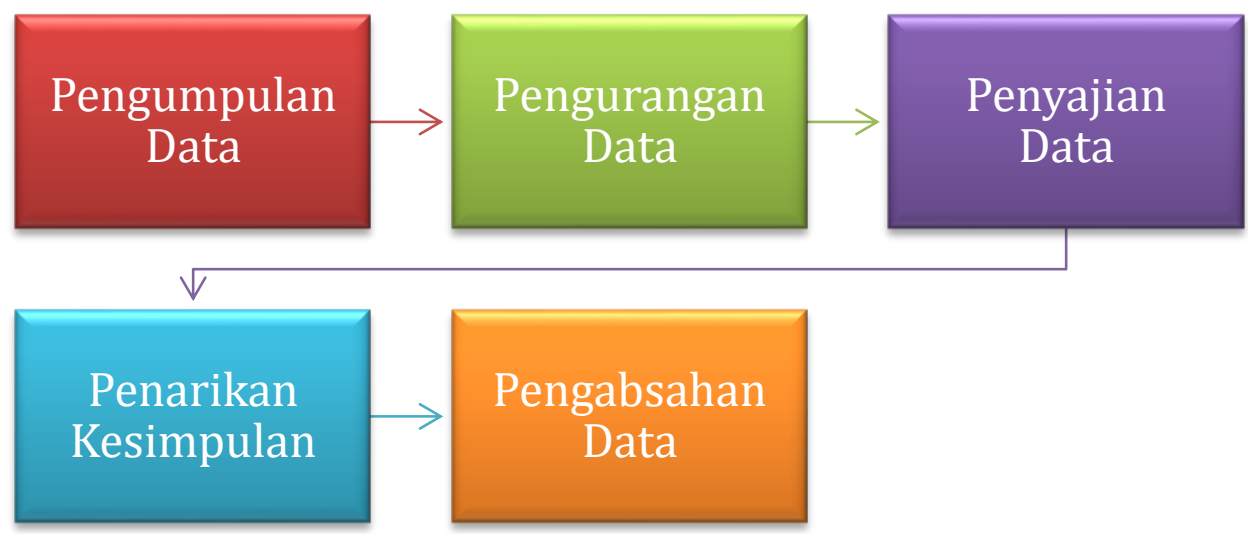

Keterangan:

Pertama: Pada tahap pengumpulan data, peneliti mengumpulkan seluruh informasi terkait macam-macam multimedia interaktif yang digunakan oleh dosendosen PBA di IAIN Palangka Raya. Multimedia yang digunakan baik secara langsung dalam proses pembelajaran di kelas, maupun tidak langsung, seperti dalam penugasan, ataupun daring atau pembelajaran mandiri secara online. Adapun hasil penelitian yang didapatkan yaitu ada macam multimedia interaktif yang digunakan yaitu e-simak Learning IAIN Palangka Raya, Arabic online, multimedia powerpoint dengan menggunakan active presenter, camtasia, cartoon story maker, plotagon, e-book learning, e-module, youtube, kine master, arabee, blogspot, zoom meeting room, google class room dan adobe flash.

Kedua: Peneliti menyaring seluruh informasi dengan menyesuaikan hasil informasi yang didapatkan dengan observasi lapangan yang peneliti lakukan dan data dokumentasi yang peneliti dapatkan, dengan skala waktu yang telah ditentukan. Dari hal ini terjadi pengurangan data yang didapatkan oleh peneliti sebelumnya setelah adanya konfirmasi dan perbandingan secara menyeluruh antara hasil wawancara, observasi dan dokumentasi sehingga multimedia interaktif yang digunakan oleh dosen PBA di IAIN Palangkaraya yaitu e-simak Learning IAIN Palangka Raya, Arabic online, multimedia powerpoint dengan menggunakan active presenter, camtasia, cartoon story maker, plotagon, e-book learning, e-module, youtube, kine master, arabee dan adobe flash.

Ketiga: Penyajian data, pada tahap inilah peneliti memilah dan menyajikan data dengan mengurut informasi dan mengklasifikasikannya. Keempat: Penarikan Kesimpulan, pada tahap ini peneliti menarik kesimpulan dari semua informasi yang telah dihasilkan. Dan terakhir adalah pengabsahan data.

Kelima: Pengabsahan data, pada tahap ini peneliti mengabsahkan data dengan tekhnik analisis triangulasi yang mana peneliti memeriksa keabsahan data dengan memanfaatkan sesuatu yang lain di luar data itu untuk keperluan pengecekan atau sebagai pembanding terhadap data yang telah dihasilkan dengan runtutan kegiatan sebagai berikut: (1) Membandingkan data hasil pengamatan dengan data hasil wawancara dengan dosen PBA, para mahasiswa dan rekan sejawat para dosen. (2) Membandingkan apa yang dikatakan orang di depan 
umum dengan apa yang dikatakan secara pribadi. (3) Membandingkan apa yang dikatakan orang-orang tentang situasi penelitian dengan apa yang dikatakannya sepanjang waktu. (4) Membandingkan keadaan dan perspektif seseorang dengan berbagai pendapat dan pandangan masyarakat dari berbagai kelas. (5) Membandingkan hasil wawancara dengan isi suatu dokumen yang berkaitan.

Pada prodi PBA di IAIN Palangka Raya adalah: Pendayagunaan multimedia interaktif ini telah berlangsung sejak lama, dan banyak digunakan oleh dosendosen PBA, untuk memperkaya bahan ajar yang diajarkan kepada peserta didik selama perkuliahan. Maka disini peneliti dapat menyimpulkan pendayagunaan multimedia interaktif yang dilaksanakan oleh dosen-dosen PBA di IAIN Palangka Raya dapat diklasifikasikan sebagai berikut:

Yang pertama, dilihat dari segi waktu dan tempat pelaksanaanya. Dosendosen PBA IAIN Palangka Raya menggunakan multimedia interaktif tidak terbatas hanya pada dikelas, ketika sedang berlangsung kegiatan pembelajaran, namun juga penggunaan media ini, dapat dilaksanakan diluar dari kegiatan pembelajaran dikelas. Multimedia ini juga dapat digunakan untuk saling berkomunikasi, baik itu tanya jawab maupun diskusi. Dengan multimedia ini diharapkan dapat membangun komunikasi lebih lanjut dengan mahasiswa terkait pembelajaran. Mahasiswa dapat berkomentar, berdiskusi, memberikan tanggapan terhadap pembelajaran yang ia dapatkan, dengan multimedia interaktif ini juga, mahasiswa dapat mengakses, setiap bahan ajar dari pertemuan pertama hingga pertemuan terakhir. Sehingga tidak ada batasan waktu, apabila mahasiswa ingin mengulang kembali pembelajaran yang sebelumnya sudah ia pelajari. Ataupun apabila ada sesuatu yang tidak memungkinkan dosen memberikan pembelajaran secara langsung, maka multimedia interaktif seperti ini sangat bermanfaat untuk digunakan. Prinsif ini sejalan dengan pendapat Mubarak dkk, yaitu melalui multimedia proses pembelajaran bahasa Arab menjadi sangat fleksibel karena dapat dilakukan di manapun dan kapanpun (Mubarak et al., 2020). Selain itu, multimedia interaktif jenis ini, support pada segala jenis file, seperti video, audio, gambar, animasi, file dokumen baik itu word maupun powerpoint. Adapun multimedia yang digunakan adalah multimedia interaktif Simak e-learning IAIN Palangka Raya (http://simak.iain-palangkaraya.ac.id/simak).

Simak e-learning ini merupakan multimedia berbasis e-learning yang digunakan oleh segenap dosen IAIN Palangka Raya termasuk dosen PBA, adapun fungsi utamanya adalah menjadi pangkalan data bidang pembelajaran IAIN Palangka Raya sekaligus menjadi sarana belajar dengan memanfaatkan fitur fitur media pembelajaran yang terdapat didalamnya, seperti document, powerpoint, gambar dan video. Selain simak e-learning, dosen PBA juga menggunakan Arabic online (https://arabic.seu.edu.sa/) yang dapat diakses oleh semua mahasiswa/I PBA untuk mengembangkan kemampuan berbahasa. Serta e-learning yang dibuat sendiri oleh Dosen PBA (Bahasaarab312.gnomio.com). Baru-baru ini, karena perkembangan teknologi informasi, ada banyak perubahan dalam kegiatan dan peralatan pembelajaran. Misalnya, dibandingkan dengan pembelajaran berbasis buku teks tradisional, e-learning telah membebaskan peserta didik dari batasan spasial-temporal, dan media pendidikan lainnya menggantikan buku teks. Secara khusus, video pendidikan telah menjadi sangat populer (Jung et al., 2019). 
Hasil penelitian Haniah menyebutkan bahwa Fasilitas yang dapat dimanfaatkan mahasiswa dengan menggunakan e-learning, di antaranya adalah $e$ book, e-library, interaksi dengan pakar, email, mailing-list, news group, world wide web (www), bahan ajar berupa video dan lain-lain (Haniah, 2014). Ditambahkan pula oleh Abusiri dkk, e-learning sebagai media elektronik dapat membawa dampak perubahan pada proses pembelajaran. Interaksi antara pengajar dan peserta didik, dalam hal ini dosen dan mahasiswa tidak hanya dapat dilakukan dengan tatap muka langsung tetapi juga dapat menggunakan media elektronik sebagai perantara sehingga suasana proses perkuliahan menjadi lebih menarik, visual dan interaktif (Abusiri et all, 2020).

Kedua, dilihat dari materi yang diajarkan. Dosen-dosen PBA IAIN Palangka Raya, menggunakan multimedia Interaktif yang beragam, masing-masing dosen menggunakan multimedia Interaktif yang sesuai dengan keperluan pada materi yang diajarkan itu sendiri. (1) Sebagaimana pada mata kuliah Maharah Istima' dosen PBA menggunakan multimedia powerpoint yang mencakup media cartoon story Maker dan juga Arabic Online untuk memaksimalkan proses pembelajaran. Dosen tersebut mengakui bahwa mata kuliah Maharah Istima' sangat perlu untuk diberdayakan multimedia Interaktif karena dalam proses pembelajarannya tidak terlepas dari penggunaan multimedia, sebagai sumber belajar, media belajar dan evaluasi pembelajaran. Tampi menyebutkan bahwa media cartoon story maker merupakan salah satu media kekinian yang dapat digunakan untuk memvisualisasikan audio atau pun teks yang didengarkan, sehingga dapat memudahkan mahasiswa pemula yang baru belajar bahasa Arab (Tampi, n.d.).

(2) pada mata kuliah Nahwu dan Sharaf, dosen PBA menggunakan multimedia interaktif berbasis software dan aplikasi seperti camtasia, active presenter, dan e-book learning, juga youtube. Penggunaan berbagai multimedia interaktif ini untuk satu mata kuliah adalah dengan tujuan agar mata kuliah ini tidak menjadi momok yang menakutkan untuk sebagian mahasiswa yang sama sekali belum pernah belajar qawaid Nahwu, dengan penggunaan multimedia, dosen PBA dapat menjelaskan dengan satu kali penjelasan, namun dapat didengar atau dilihat oleh mahasiswa berulang kali. Karena diketahui bahwa mata kuliah Nahwu merupakan salah satu mata kuliah yang berat bagi sebagian peserta didik, sebagaimana disebutkan oleh Hakim bahwa dari sudut pandang pembelajar bahasa Arab, justru kaidah nahwu ini dianggap sebagai sesuatu hal yang paling sulit dan melelahkan untuk dipelajari (Hakim, 2014). Hal ini bisa kita lihat sampai pembelajar bahasa Arab masih sulit untuk menerapkan kaidah nahwu dalam keterampilan berbahasa Arab mereka. Berdasarkan dari ini, maka dosen PBA mengatasinya dengan menyuguhkan beragam multimedia interaktif agar dapat memudahkan mahasiswa, misalnya dengan menggunakan penjelasan dengan berbagai contoh beragam yang terdapat di youtube dan juga memanfaatkan media active presenter untuk membuat rangkuman dari penjelasan materi yang akan dipelajari.

(3) pada mata kuliah Maharah Kalam, dosen PBA menggunakan multimedia berbasis aplikasi android yaitu kine master, plotagon, Arabee. Menurut Putra dkk, pemanfaatan multimedia berbasis android terbilang mempunyai banyak kelebihan, salah satunya yaitu karena multimedia ini ada di smartphone, mudah digunakan, mudah dibawa, mudah diakses dan terjangkau sebagai media dalam 
pembelajaran (Putra et al., 2017). Selain itu sarana pembelajaran seperti ini tergolong baru, peserta didik akan lebih tertarik untuk menggunakan sarana yang sifatnya "kekinian" dan biasa dalam kehidupan sehari-hari. Dosen PBA mengatakan bahwa dengan menggunakan multimedia ini mahasiswa dapat membuat video, baik itu wacana ataupun percakapan, secara individu, berpasangan ataupun kelompok untuk melatih kemampuan maharah kalamnya. Penelitian Mubarak dkk juga menyebutkan sudah saatnya para dosen memaksimalkan penggunaan smartphone yang notabenenya dimiliki oleh sebagian besar mahasiswa untuk hal-hal bermanfaat dibidang pembelajaran (Mubarak et al., 2020).

Yang ketiga, dilihat dari kebutuhan mahasiswa. Dosen- Dosen PBA IAIN Palangka Raya, menyadari betul bahwa sebagian besar mahasiswa/I prodi PBA IAIN Palangka Raya merupakan alumni dari sekolah umum yang diketahui bahwa kemampuan mereka dalam memahami pelajaran bahasa arab lebih lambat dibandingkan dengan teman sekelasnya yang minoritas alumni pondok pesantren, oleh sebab itu berbagai cara dilakukan agar proses pembelajaran tetap seimbang dan dapat berjalan dengan baik tanpa mengenyampingkan para mahasiswa yang lebih pintar. Salah satu cara yang dilakukan oleh dosen PBA adalah menyiapkan multimedia interaktif sesuai dengan kebutuhan mahasiswa. Kebutuhan yang dimaksudkan adalah memberikan kemudahan kepada mahasiswa untuk memfasilitasi bahan ajar yang diberikan dengan tambahan sumber belajar dari multimedia interaktif, sehingga hal ini menjadi pilihan tersendiri, untuk mahasiswa melakukan belajar mandiri maupun dimonitoring oleh dosen yang bersangkutan. Contoh multimedia interaktif yang digunakan yaitu berbasis software adalah Macromedia/ Adobe Flash. Dosen PBA menggunakan multimedia interaktif ini pada mata kuliah Tathbiq Mufradat, dengan menggunakan multimedia ini, diharapkan mahasiswa dapat mengejar ketertinggalannya diantara mahasiswa lain, dengan memperkaya kosa kata secara mandiri dirumah, dan berlatih membuat kalimat dari kosa kata tersebut. Hal ini sejalan dengan hasil penelitian Yusuf dan Rahmawati, mereka menyebutkan bahwa multimedia interaktif dengan menggunakan macromedia flash 8 terbukti efektif dalam memperkaya kosakata peserta didik, dikarenakan penggunaannya yang mudah dan sederhana juga tidak membosankan penggunanya (Yusuf \& Rahmawati, 2020).

Adapun problematika pembelajaran bahasa Arab pada prodi PBA IAIN Palangka Raya, yang dapat teratasi dengan penggunaan multimedia interaktif oleh dosen PBA ini dapat diklasifikasikan sebagai berikut:

(1) dari segi linguistik, dengan menggunakan multimedia interaktif, dosen menjadi lebih mudah dalam mendemonstrasikan bahan ajar atau materi pembelajaran kepada mahasiswa sehingga mahasiswa mendapatkan visualisasi dari materi yang diajarkan, tidak hanya melulu dengan mendengarkan ceramah dari dosen. Hal ini dapat dilihat dari, sebagaimana yang dilakukan oleh dosen PBA ketika menjelaskan mata kuliah Nahwu dan Sharaf, ada diagram diagram berupa peta konsep yang terdapat dalam multimedia interaktif, sehingga membantu mahasiswa dapat focus dan memperkuat daya ingat mereka. Dalam penelitian yang dilakukan oleh Marcellina, disebutkan bahwa salah satu multimedia yang efektif digunakan dalam pembelajaran adalah media gambar, hal ini dikarenakan media gambar dapat memberikan pengalaman langsung bagi peserta didik. 
Dengan menggunakan media gambar peserta didik akan dapat menarasikan ingatannya dalam sesuatu yang dapat divisualkan. Hasil peneltiannya menunjukkan bahwa pembelajaran dengan menggunakan media gambar terbukti dapat meningkatkan daya ingat siswa dalam pembelajaran (Marcellina, 2014).

(2) Dari segi non linguistic, dengan menggunakan multimedia interaktif, dosen PBA dapat menarik minat dan perhatian mahasiswa yang kurang mempunyai motivasi dalam belajar bahasa arab. Hal ini lumrah terjadi dikalangan pembelajar bahasa arab, sebagaimana pendapat Ritonga dkk, bahwa hegemonitas peserta didik pada lembaga pendidikan memiliki pengaruh terhadap proses pembelajaran khususnya bahasa Arab. Peserta didik yang memiliki pengetahuan awal tentang bahasa Arab setidaknya telah mengenal dan mengetahui makna beberapa kosa kata yang sering digunakan dalam kehidupan sehari-hari. Berbeda dengan peserta didik yang tidak memiliki pengetahuan dasar sama sekali tentang bahasa Arab, mereka seakan merasa tertinggal dari teman sekelasnya sehingga motivasi belajar mereka menurun (Ritonga et al., 2016). Ditambah lagi dengan keterbatasan dosen dalam menjelaskan bahan ajar, yang tidak dapat dicerna semua level kecerdasan peserta didik. Karena memang kemampuan peserta didik pada dasarnya berbeda-beda. Sebagaimana diungkapkan oleh Amiruddin, yaitu salah satu problematika non linguistik, yang kadang terabaikan adalah diantaranya dari unsur pengajar, pengajar kurang memiliki kompetensi social yang sebenarnya dibutuhkan oleh peserta didik dengan berbagai macam karakteristik, latar belakang dan kemampuan kecerdasan yang berbeda-beda (Admin \& Amirudin, 2017). Hal ini juga menjadi salah satu problematika pembelajaran bahasa Arab non linguistic yang diharapkan dapat teratasi dengan penggunaan multimedia interaktif, yang mana multimedia pada dasarnya dapat diterima semua kalangan, khususnya generasi muda.

Dari hasil penelitian diatas, maka dapat disimpulkan bahwa penggunaan multimedia interaktif digunakan sebagai suplemen belajar. Multimedia interaktif yang digunakan beragam, sama sekali tidak ada batasan ataupun ketentuan yang mengatur, sehingga disini, dosen PBA dapat menjadi lebih kreatif mengelola kegiatan pembelajarannya sehingga mahasiswa menjadi lebih bersemangat dalam belajar, dengan kegiatan pembelajaran yang lebih variatif. Hal ini tidak lain dan tidak bukan dimaksudkan sebagai usaha dalam mengatasi problematika pembelajaran bahasa Arab yang ada pada prodi PBA IAIN Palangka Raya.

\section{Kesimpulan}

Multimedia interaktif dalam mengatasi problematika pembelajaran bahasa Arab oleh dosen PBA IAIN Palangka Raya, dapat diklasifikasikan sebagai berikut: Yang pertama, dilihat dari segi waktu dan tempat pelaksanaanya. Adapun multimedia yang digunakan adalah multimedia interaktif Simak e-learning IAIN Palangka Raya, Arabic online dan Bahasaarab312.gnomio.com. Kedua, dilihat dari materi yang diajarkan. Adapun multimedia Interaktif yang digunakan sesuai dengan keperluan pada materi yang diajarkan itu sendiri. Contohnya: 1) pada mata kuliah Maharah Istima' dosen PBA menggunakan multimedia powerpoint yang mencakup media cartoon story Maker dan juga Arabic Online untuk memaksimalkan proses pembelajaran. 2) pada mata kuliah Nahwu dan Sharaf, dosen PBA menggunakan multimedia interaktif berbasis software dan aplikasi 
seperti camtasia, active presenter, dan e-book learning, juga youtube. 3) pada mata kuliah Maharah Kalam, dosen PBA menggunakan multimedia berbasis aplikasi android yaitu kine master, pollagon, Arabee. Yang ketiga, dilihat dari kebutuhan mahasiswa. Kebutuhan yang dimaksudkan adalah memberikan kemudahan kepada mahasiswa untuk memfasilitasi bahan ajar yang diberikan dengan tambahan sumber belajar dari multimedia interaktif, sehingga hal ini menjadi pilihan tersendiri, untuk mahasiswa melakukan belajar mandiri maupun dimonitoring oleh dosen yang bersangkutan. Contoh multimedia interaktif yang digunakan yaitu berbasis software adalah Macromedia/ Adobe Flash. Dosen PBA menggunakan multimedia interaktif ini pada mata kuliah Tathbiq Mufradat.

Adapun problematika pembelajaran bahasa Arab pada prodi PBA IAIN Palangka Raya, yang dapat teratasi dengan penggunaan multimedia interaktif oleh dosen PBA ini dapat diklasifikasikan sebagai berikut: 1) dari segi linguistik, dengan menggunakan multimedia interaktif, dosen menjadi lebih mudah dalam mendemonstrasikan bahan ajar atau materi pembelajaran kepada mahasiswa sehingga mahasiswa mendapatkan visualisasi dari materi yang diajarkan. 2) dari segi non linguistic, dengan menggunakan multimedia interaktif, dosen PBA dapat menarik minat dan perhatian mahasiswa yang kurang mempunyai motivasi dalam belajar bahasa arab.

\section{Referensi}

Abusiri, Ekawati, Khotimah, (2020). Implementasi E-Learning Dalam Upaya Meningkatkan Kreativitas Dosen Dan Mahasiswa Di Stai Alhikmah Jakarta. Hikmah, Vol. Xv, No. 1, 2019

Admin, A., \& Amirudin, N. (2017). Problematika Pembelajaran Bahasa Arab. TAMADDUN, 1-12. https://doi.org/10.30587/tamaddun.v0i0.66

Angelina, M., \& Hamdun, D. (2019). Pengembangan Media Pembelajaran Ta'bīr Berbasis Permainan Uno Stacko pada Siswa MA Ibnul Qoyyim Putra Yogyakarta. al Mahāra: Jurnal Pendidikan Bahasa Arab, 5(2), 209-232. https://doi.org/10.14421/almahara.2019.052.04

Armawi, S. A. S. (2018). Pendayagunaan Multimedia Dalam Pengajaran Bahasa Arab. Jurnal Al Mabhats, 3(1), 01-23.

Baso, Y. S. (2008). Penggunaan Multimedia Interaktif Dalam Pembelajaran Bahasa Arab. Nady Al-Adab, 5(2), 48-54.

Binanto, I. (2010). Multimedia Digital-Dasar Teori dan Pengembangannya. Penerbit Andi.

Dosen PBA mengikuti Workhsop Pembuatan Video Pembelajaran Interaktif dan EModule 4.0. (n.d.). Retrieved March 29, 2020, from http://pba.ftik.iainpalangkaraya.ac.id/2020/02/dosen-pba-mengikuti-workhsoppembuatan.html

Fahrurrozi, A. (2014). Pembelajaran Bahasa Arab: Problematika dan Solusinya. Arabiyat: Jurnal Pendidikan Bahasa Arab Dan Kebahasaaraban, 1(2), 161180. https://doi.org/10.15408/a.v1i2.1137 
Hakim, A. R. (2014). Mempermudah Pembelajaran Ilmu Nahwu pada Abad 20. Jurnal Al Maqayis, 1(1). https://doi.org/10.18592/jams.v1i1.96

Handayani, T. (2017). Peningkatan Keterampilan Bermain Drama Pada Mata Pelajaran Bahasa Indonesia Melalui Model Role Playing Berbantuan Multimedia Kelas V SDN 01 Rajekwesi Jepara [Undergraduate, Fakultas Keguruan dan Ilmu Pendidikan UNISSULA]. http://repository.unissula.ac.id/10226/10/BAB\%20V.pdf

Haniah, H. (2014). Pemanfaatan Teknologi Informasi dalam Mengatasi Masalah Belajar Bahasa Arab. Al-Ta'rib: Jurnal Ilmiah Program Studi Pendidikan Bahasa Arab Palangka Raya, 2(1). https://doi.org/10.23971/altarib.v2i1.588

Jarot.S, \& Ananda. (2009). Buku Pintar Multimedia. MediaKita.

Jung, S., Son, M., Kim, C., Rew, J., \& Hwang, E. (2019). Video-based learning assistant scheme for sustainable education. New Review of Hypermedia and Multimedia, 25(3), 161-181. https://doi.org/10.1080/13614568.2019.1678682

Lin, V., Liu, G.-Z., Hwang, G.-J., Chen, N.-S., \& Yin, C. (2019). Outcomes-based appropriation of context-aware ubiquitous technology across educational levels. Interactive Learning Environments, $0(0), \quad 1-24$. https://doi.org/10.1080/10494820.2019.1703012

Marcellina, E. (2014). Penggunaan media gambar untuk meningkatkan daya ingat siswa dalam pembelajaran IPS kelas IV MI Mambaul Ulum Tirtomoyo Pakis Malang [Undergraduate, Universitas Islam Negeri Maulana Malik Ibrahim]. http://etheses.uin-malang.ac.id/7745/

Mubarak, M. R., Wahdah, N., Ilmiani, A. M., \& Hamidah, H. (2020). Penggunaan VLOG dalam Pembelajaran Maharah Kalam. Al Mi'yar: Jurnal Ilmiah Pembelajaran Bahasa Arab dan Kebahasaaraban, 3(1), 109-126. https://doi.org/10.35931/am.v3i1.209

Nugrawiyati, J. (2018). Media Audio-Visual Dalam Pembelajaran Bahasa Arab. ElWasathiya: Jurnal Studi Agama, 6(1), 97-111. https://doi.org/10.5281/zenodo.3523167

Putra, R. S., Wijayati, N., \& Mahatmanti, F. W. (2017). Pengaruh Penggunaan Media Pembelajaran Berbasis Aplikasi Android Terhadap Hasil Belajar Siswa. Jurnal Inovasi Pendidikan Kimia, 11(2), Article 2. https://journal.unnes.ac.id/nju/index.php/JIPK/article/view/10628

Rho, S., \& Kang, D. (2019). Introduction to the special issue on advances in multimedia and educational technology. New Review of Hypermedia and Multimedia, 25(3), 87-88. https://doi.org/10.1080/13614568.2019.1706244

Ritonga, M., Nazir, A., \& Wahyuni, S. (2016). Pembelajaran Bahasa Arab Berbasis Teknologi Informasi dan Komunikasi di Kota Padang. Arabiyat: Jurnal Pendidikan Bahasa Arab dan Kebahasaaraban, 3(1), 1-12. https://doi.org/10.15408/a.v3i1.2879 
Rukimin, R. (2016). Multimedia Interaktif Dalam Pembelajaran Bahasa Arab. Prosiding Seminar Nasional Teknologi Pendidikan, $0(0)$, Article 0. http://www.jurnal.fkip.uns.ac.id/index.php/psdtp/article/view/9054

Sadiman, A. S. (2019). Media Pendidikan pengertian, pengembangan dan pemanfaatannya. http://r2kn.litbang.kemkes.go.id:8080/handle/123456789/61227

Tampi, Y. (n.d.). Implementasi Media Cartoon Story Maker Dengan Model Pembelajaran Langsung Untuk Meningkatkan Reading Comprehension Siswa Kelas IXa SMPN 1 Tamiang Layang. 13.

Yasmar, R. (2017). Multimedia Interaktif Pembelajaran Bahasa Arab Untuk Siswa Madrasah Aliyah. Arabiyatuna: Jurnal Bahasa Arab, 1(2), 199-216. https://doi.org/10.29240/jba.v1i2.325

Yusuf, M., \& Rahmawati, E. D. (2020). Optimalisasi Aplikasi Macromedia Flash 8 Dalam Pembelajaran Kosakata Bahasa Arab. Al-Lisan: Jurnal Bahasa (eJournal), 6(1), 17-33. https://doi.org/10.30603/al.v6i1.1102

\section{Copyright Notice}

Authors retain copyright and grant the journal right of first publication with the work simultaneously licensed under a Creative Commons Attribution 4.0 International License that allows others to share the work with an acknowledgement of the work's authorship and initial publication in this journal. 